\title{
فعالية برنامج مقترح فى الدراسات الاجتماعية قائم على النظرية البنائية \\ فى تنمية بعض مهارات التفكير التأملى والقدرة على اتخاذ القرار لدى تلاميذ المرحلة الإعدادية
}

\author{
هبة السيد عبر السميع السيد
}

$$
\begin{aligned}
& \text { الملخص } \\
& \text { هدفت هذه الدراسة تعرف فعالية برنامج مقترح في الدراسات الاجتماعبة قائم على النظرية البنائية } \\
& \text { ية مهارات التفكير التأملي والقدرة على اتخاذ القرار لدى تلاميذ العرحلة الإعدادية ، وتكونت عينة } \\
& \text { الدراسة من (•V) تلميذة من تلاميذ الصف الثاني الإعدادي من إدارة غــرب المنــصورة التعليهيــة،وتم }
\end{aligned}
$$

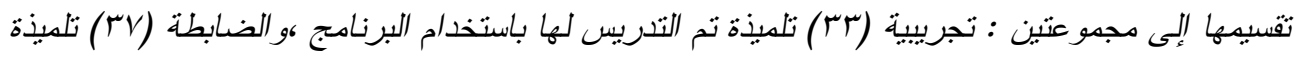

$$
\begin{aligned}
& \text { تم التنريس لها باستخدام الطريقة الدعتادة . } \\
& \text { وقد أعدت الباحثة اختباري مهارات التفكبر التأملي والقدرة على اتخاذ القرار، وتم تطبيق الأدوات }
\end{aligned}
$$

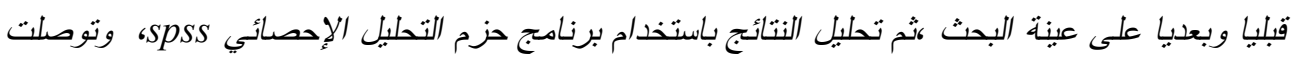

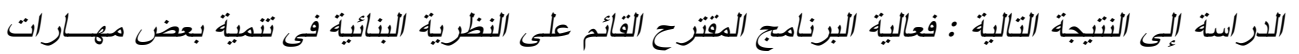

$$
\begin{aligned}
& \text { التفكير التأملى و القدرة على اتخاذ القرار لدى تلاميذ المرحلة الاعدادية. }
\end{aligned}
$$

\section{Abstract}

The present study aims at determining the Effectiveness of a proposed constructivism - Based program in social studies in developing some Reflective thinking skills and Decision Making Ability of prep stage pupils .

The instruments of the study are Reflective thinking skills test and Decision Making Ability test .

A sample of study from second year of prep female pupils at Tanah prep school for girls that represent the experimental group and at Meet Aly prep school for girls that represent the control group , the researcher applied two instrument pre and post administration to the sample of study

The results of the study is the Effectiveness of a proposed constructivism Based program in social study in developing some Reflective thinking skills and Decision Making Ability of the experimental group

Kay words : program, constructivism, Reflective thinking, Decision Making Ability, social studies ,prep stage pupils 


\section{المقدمة :}

و التى تتطلب منه التفكير فيها، ومن هنا لابد من تدريب التلميذ على مر احل اتخاذ القـــرار فى هذا الثأن من خلال محتوى التعلم المقدم

له ، ، وذلك باستخدام نماذج تدريسية بنائية .

\section{الإحساس بالشكلة:}

يؤكد العديد من التربويين منل عاطف

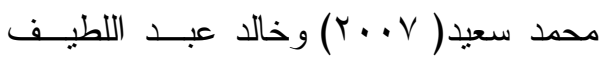

عمر ان( ؟ . . Y) و السعيد الجندى عبد العزيز

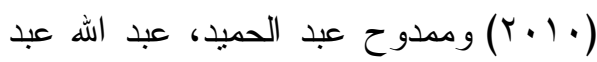

الخالق( (1) (1) أن الو اقع الحالى لتعليم مادة

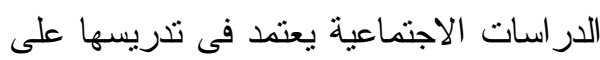

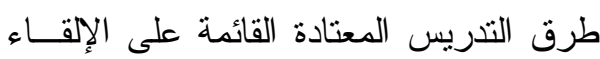

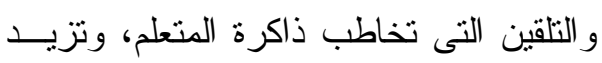

من سلبيته فى عملية التعلمهو عــدم تــصميم

المو اقف التعليمية التى يمكن من خلالها تتمية

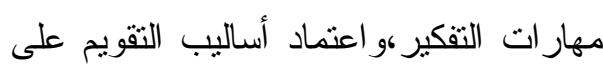
قياس الحفظ و التذكر و إهمال التفكير .

وقد تعالت الانتقادات الموجهــة إلـى

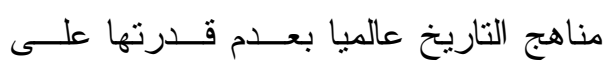

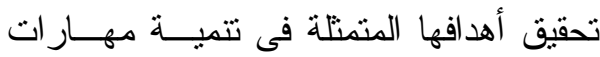
التقكير، لذا بدأت الـــدعوة لإحيــاء منــــاهج التاريخ لتو اكب التغيرات المنوقعة فى القرن

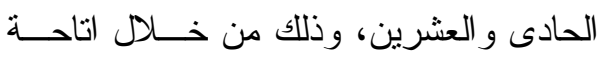
الفرصة للتناميذ القيام بالمناةـشات و واتخــاذ

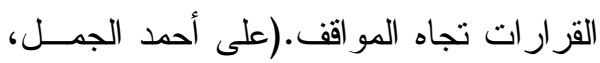

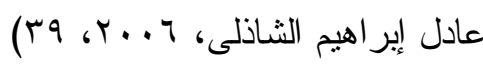

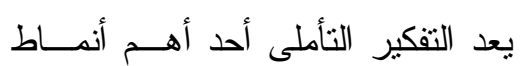

التفكير الذى يجعل المــتعلم يتأمـلـل المـــادة

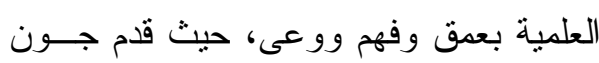

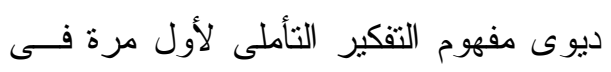

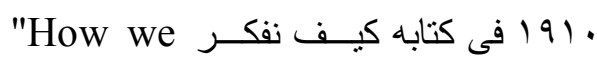
" think" يتحسن إلى الارجة النى ينشأ فيها من عملية التأمل. (عـاطف محمــد ســعيد، V...

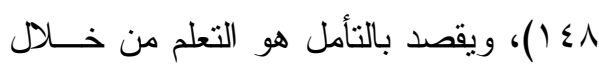

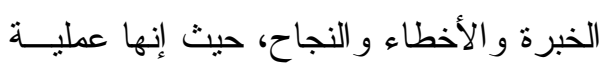
وعى ذاتى من خلال القيام بالتحليلات النقدية

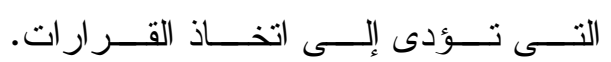
(WILSON, 2008, 252 ) ومن أجل تتمية التفكير التأملى فلابــــ

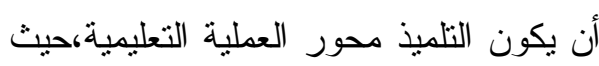

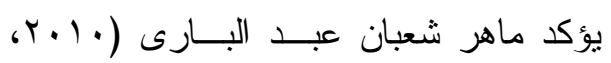
10) 1/Yلى أن النظرية البنائية تحول النزكيز

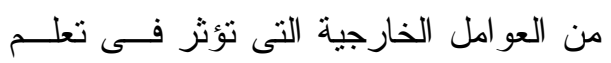
الطالب مثل المعلــم و المدرســـة و المــنهج و الأقران ، إلى التركيز على العو امل الداخلية

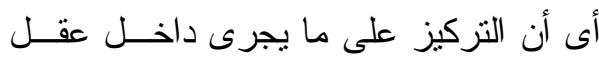

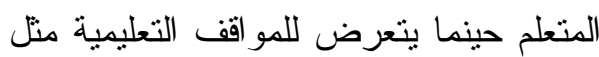
معرفته السابقة، معالجة المعلومات، ودافعينة للتعلم، و أنماط تقكيره . وتشمل مادة الدراســات الاجتماعيــة

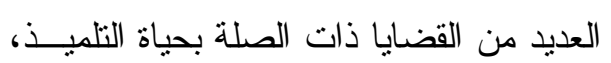


بنائها و تصميمها، و أيضا طرق تدريسها بما يسمح بتتمية مهار ات التفكير المتتوعة. فيعد التفكير التأملى من أهــــ أنـــاط التفكير التى ينبغى تتميتها لــدى المتعلمـين فين

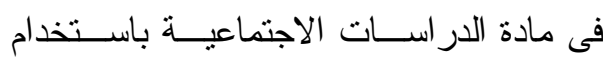

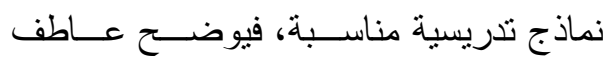

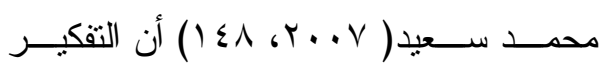

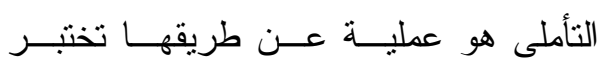
الموضوعات و النتائج وذللك عندما نقوم بحل

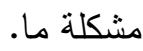
وفى ظل المدخل البنائى وما يتضمنه

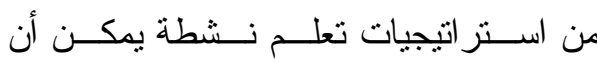

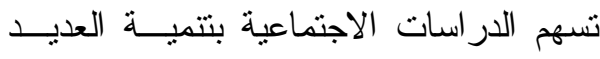

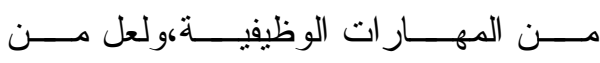

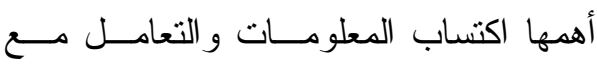
البيانات و إنشاء معرفــة جديـــــة و اكتــــاب

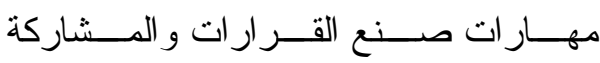

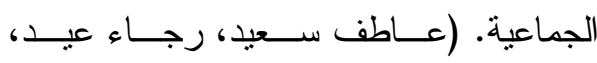

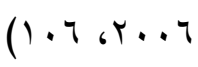

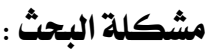
تم صياغة مشكلة البحــث فـــي الـــؤال الرئيسى التالى:

ما فعالية برنامج مقتر ح فى الدر اسات

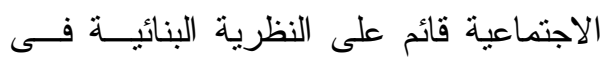
تتمية بعض مهار ات التفكير التأملى و القــدرة

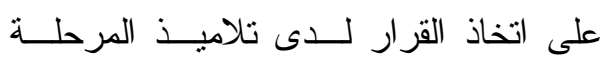
الإعدادية ؟
وان واقع تدريس الجغرافيــا فـــى مراحـل التعليم العام يواجه صعوبات منها: عدم إلمام المتعلمــين بجــوهر مــادة الجغر افيا، ونتيجة لذلك ابتعدو ا عن التفكيــر

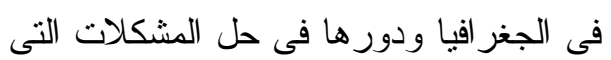

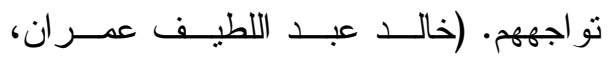
$(V)-V \cdot{ }^{2} r \cdot . q$ وللكثف عن مدى الصعوبات التـى نعى تو اجه تعليم وتعلم مادة الدر اسات الاجتماعية

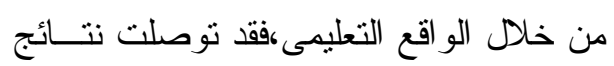
در اسة حنان إبر اهيم الدسوقى محمد (10 • ب)

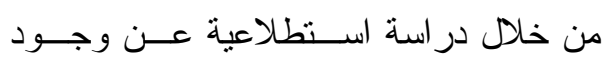

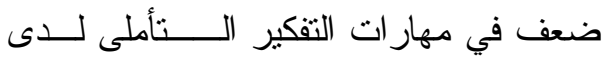
طلاب الصف الأول الثانوى .

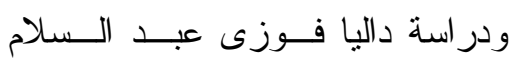

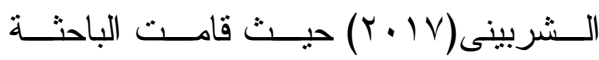

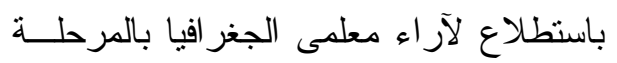

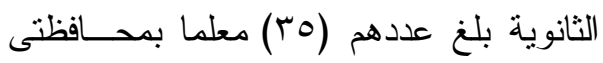

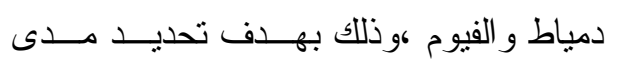

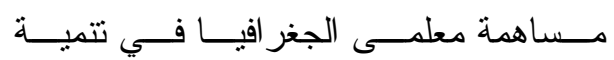

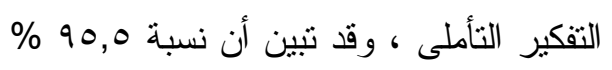

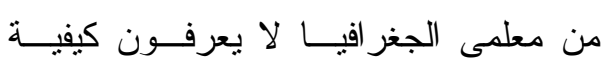

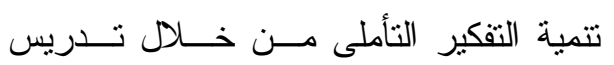
الجغر افيا. ومن هنا يجب إعادة النظر فى تطوير مناهج الدراسات الاجتماعية سو اء من حيث 


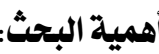

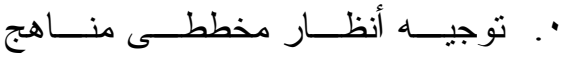

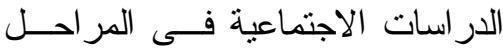
التعليمية المختلفة إلى ضرورة نطوير تللك المناهج وفقا لأسس وفكر النظرية

البنائية.

•. . تقديم اختبار مهارات التفكير التــأملى واختبار اتخاذ القرار كأدوات يمكـنـن

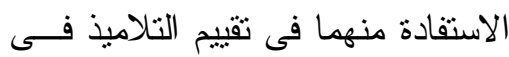
مادة الدر اسات الاجتماعية.

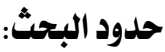

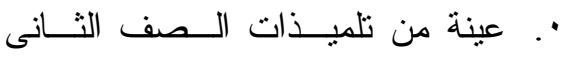
الإعدادى من مدرسة طناح الإعدادية بنات تمنل المجموعة التجريبية ، ومن الإع مدرسة ميت على الإعداديـــة بنــات تمثل المجموعة الضابطة.

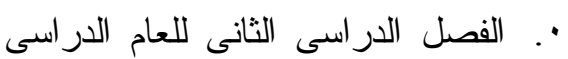
. $r \cdot 11 / r \cdot 1 V$ منهج البحث:

•. المنهج الوصفى التحليلى: لاســنقر اء

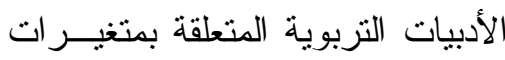

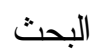
•. المنهج التجريبى: لتحديد مدى فعالية

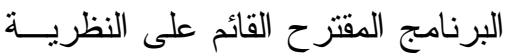

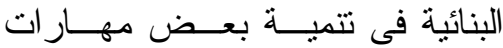

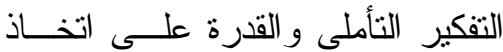
القرار لدى تلاميذ المرحلة الإعدادية
ويتفرع عن هذا السؤال الرئيس التساؤلات الفرعية التالية:

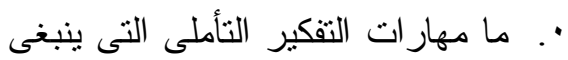
تو افرها لدى تلاميذ المرحلة الإعدادية فى مادة الدر اسات الاجتماعية؟

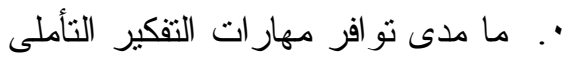
لاى تلاميذ المرحلة الإعدادية؟

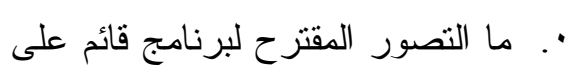
النظرية البنائية لتنمية بعض مهار ات

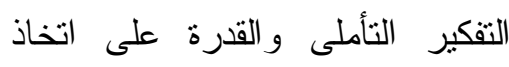
القرار لدى تلاميذ المرحلة الإعدادية فى مادة الدر اسات الاجتماعية؟ •. ما فعالية استخدام البرنامج المقترح فى تتمية بعض مهارات التفكير التأملى لدى تلاميذ المرحلة الإعدادية؟ لعمئ لهاب • . ما فعالية استخدام البرنامج المقترح فى تتمية القدرة على اتخاذ القرار لاى لدى تلاميذ المرحلة الإعدادية؟

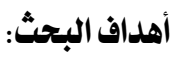
• . تعرف مدى فعالية استخدام البرنــامج

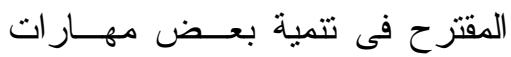

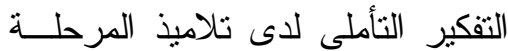

$$
\text { الإعدادية. }
$$

• . تعرف مدى فعالية استخدام البرنــامج

المقتر ح فى تتمية القدرة على اتخــاذ القرار لدى تلاميذ المرحلة الإعدادية. 


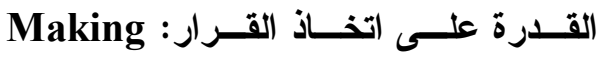

يعرف اتخاذ القرار إجر ائيا بأنه: قدرة

التلميذ على وضع حلول وبدائل للمـشكلات الجغر افية و المو اقف التاريخيــة ، و واختبــار أفضل هذه الحلول وفقا لمعايير منطقية بعـد ولد وليد

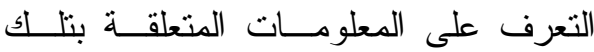
المشكلات و التعرف على أبعادها ودر اســتها بطريقة منظمة - مئمة أدبيات البحث المحور الأول : البنائية

:Constructivism

يـــــــ "بياجيـــــة " أن الفــــرد

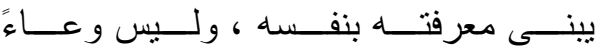
فارغا تسكب فيـــه المعرفـــة ، وأن البنيـــة

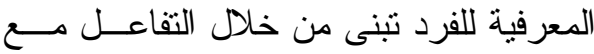

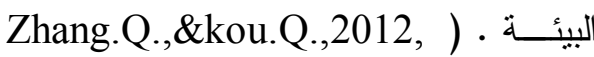

وتتسم بيئة التعلم البنائى بالعديد مسن الخصائص التى تمبز ها عن غيرها ؛ حيــث يعرضها كـورت (Kurt.s.,2011. 3981) موضحا بأنها : نوفر الخبرة للمتعلم من أجل

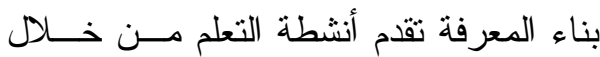

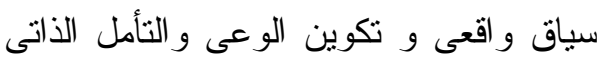

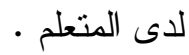

تعرف الباحثة البرنامج إجر ائيا: بأنــهـ

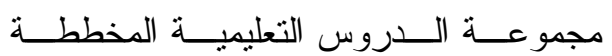
و المنظمة فى ضوء طبيعة النظرية البنائيــة ونماذجها التدريسية بغرض تحقيق أهـداف

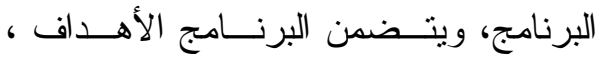
و المحتوى ، وطرق التــدريس، و الوســائل و الأنشطة التعليمية ، و أساليب التقويم.

\section{Theory} (البنائي النظريـا

\section{:Constructivism}

تعرف خديجة محمد سعيد( · ب r ،

r T ) النظرية البنائية بأنها منظومة نربوية

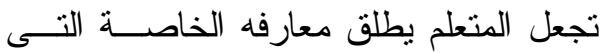
يخزنها بداخله ليصل عن طريقها إلى معرفة

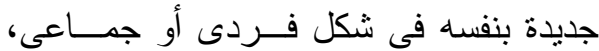

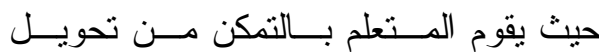
المعلومات وتكــــين الفرضـــات، واتخـــاذ

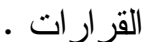

\section{Reflective thinking التفكير التأملى :}

تعــرف الباحثـــة التفكيــر التــــلى

إجر ائيا: بأنه العمليات العقلية التى يقوم بهـــا المتعلم عند تفاعله مع المحتــوى التعليمسى المقدم له و التأمل و التعمق فى فهمه و القيــام بالعديد من الأنشطة العقلية الذهنية كالتفـسير

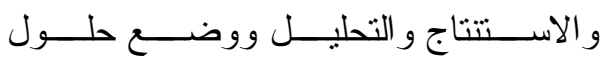


الطلاب بدلا من خطة الدرس.يحقق التو اصل

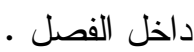

ويستكمل ديميرس ( Demirci.C.,

280, 2010 ميزات و أدوار المعلم البنائيــة،

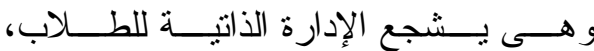

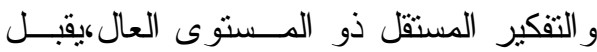
روح المبادرة من قبــلـل الطــلاب واحتــــــام أر ائهم و يوفر الفرص لتحليـلـل المـشكلات

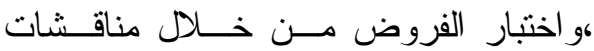

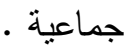

واهتمت الدراســات بــالتحقق مسن

الأهمية التربوية للنظريــة البنائيــة ،ومــن بينها:در اسة " كيلس " و" جوردل " (2010) Kilic,o.,\&Gurdal.A

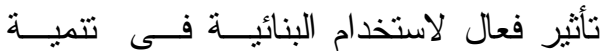

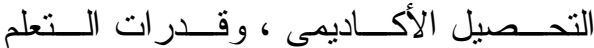
المفاهيمى لدى تلاميذ المدرسة الابتدائية فى

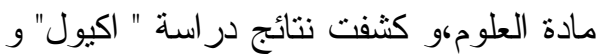

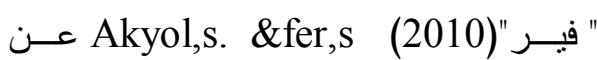
تأثنبر فعال لمدخل تعليمى بيئى اجتماعى قائم

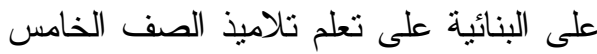

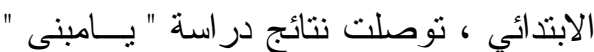
عن تأثثر نمــوذج Yampinij.s (2012) تعليمى قائم على المدخل البنائي فــى تتميــــة مهار ات حل المشكلات لدى طلاب التعلــيم الصناعى و التكنولوجى.

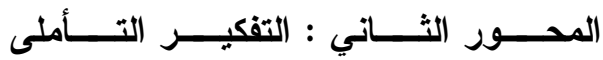

و المواد التعليمية البنائية ، يشير " كاردمان Karaduman.H.,2007,101 - تمكن المتعلم من اكتـشـاف المعرفـــة

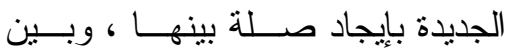

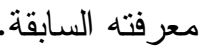

- تدعيم اســقتلالية المــتعلم وذاتيتــهـ ، و العلاقات التفاعلية مـع المتعلمـين

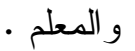
- توجه المتعلم إلى البحث عن المصادر منتـلـل : الموســــوعات وصـــــــات

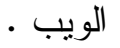

- تغطى إجابات عن أسئلة منل :كيــف نتعلم ؟ ماذا نتعلم ؟

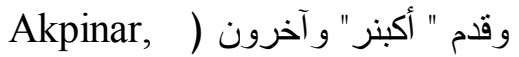
عدة بنود للتــــويم (E.,et al, 2009, 2795

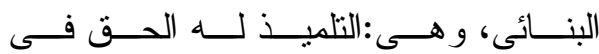
تطوير أدوات الثقويم و المعسايير الخاصـــة ويعرف نوع التقويم الذى سبطبق فى بدايــة التذريس ،و أن التقويم يعد فرصة لتحقيق تعلم أكثر و لا يتم مقارنة طالب مع آخر و التقويم

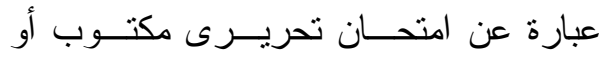
شفهى.

كما يعـرض أكبنـر

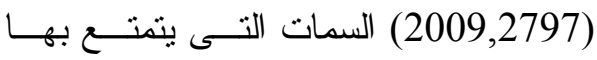
المعلم البنائى وهى يشجع التلاميذ على إيجاد

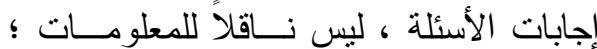
ولكن بيسر الوصول إليها، يستخدم خطة تعلم

\section{:Reflective Thinking}


التى أسفرت نتائجها عن فعاليــة تــدريس

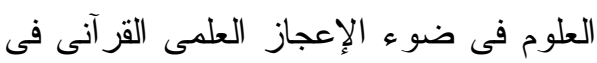

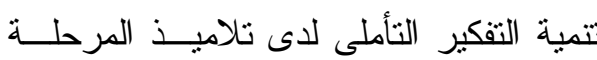
الإعدادية الأزهرية.

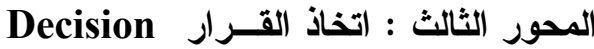

: Making

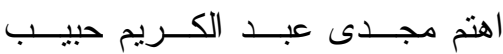

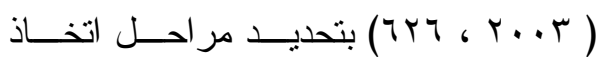

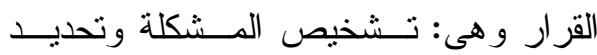
الهدف ،تحليل المشكلة ،تحديد البدائل الممكنة

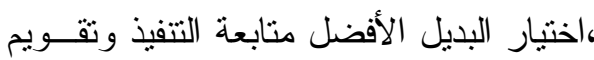
النتائج

وتوضح ليلى بنت سعد بـن ســيد

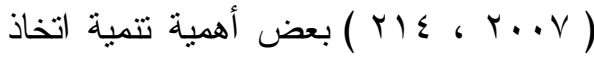

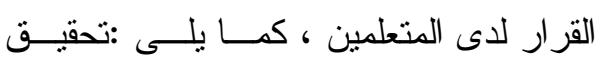

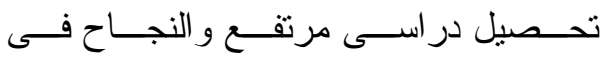
المشاركات الاجتماعيـة ،تحسـسين قــدرات التفكير ،التزيث و التأمل وتحمل المسئولية قبل

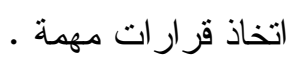

ومن الدر اسات التى اهتـــت باتخــاذ

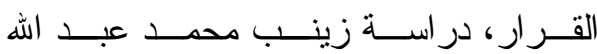

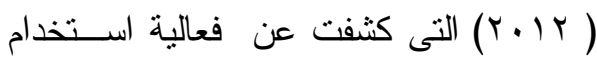
التعلم الاستر اتيجى فى تتمية مهار ات اتخاذ القرار لدى طلاب الصف الأول الثانوى فى لألى

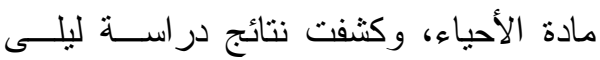

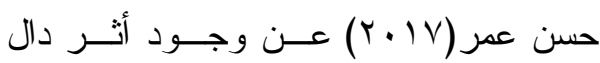

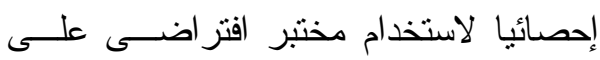

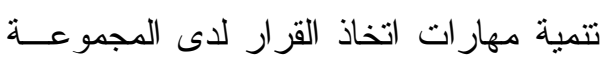

$$
\text { التجريبية. }
$$

يتضمن التفكيــر التــأملى العمليــات

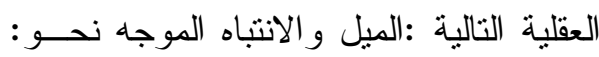

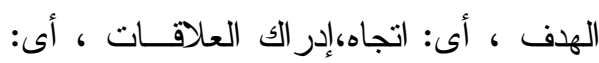

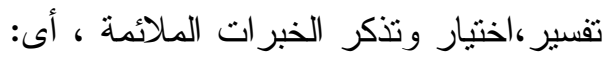
اختيار ،تميز العلاقات بين مكونات الخبــرة ،

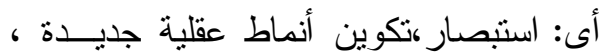
أى: ابتكار ،تقويم الحل كتطبيق عملى ، أى:

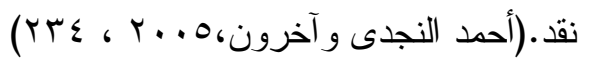

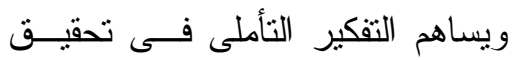

الفو ائد التالية للمتعلمين ، وهى : التفكير فى لئى

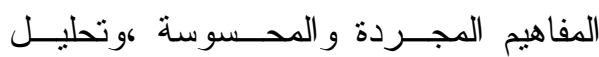
موضوعات مختلفة وتقييمها، وتتمية الشعور

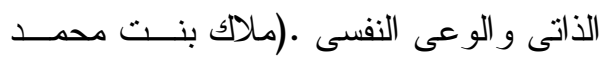

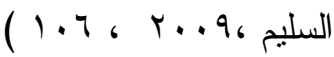

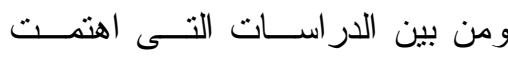

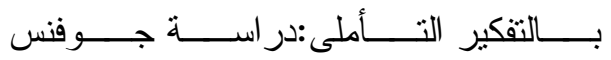
Guvenc, .Z. (2012)

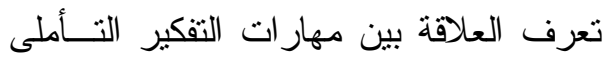

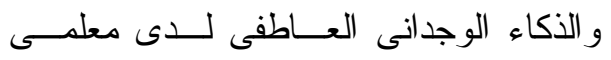

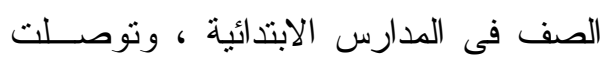

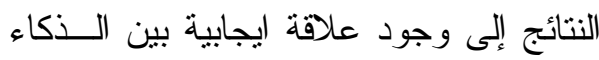
الوجدانى ومهار ات التفكير التأملى ،ودر اسة الته بين تشارونـشـا Charonchai.S(2012) التـي اهتمت بتعرف أثز العمل التعــاونى البحثى

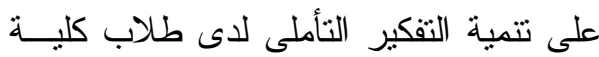
التربية ، وتوصلت النتائج إلى أن مهــار ات لتهيل التفكير التأملى نم تتميتها لدى الطلاب بشكل

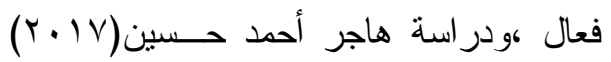




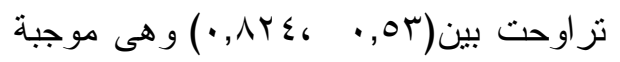

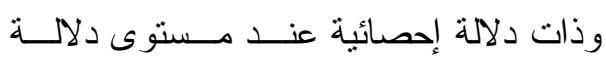

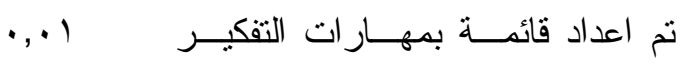

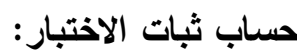
تم حساب التبات باستخدام معادلة ألفا كرونباخ لمهارات التفكير التأملى والاختبــار

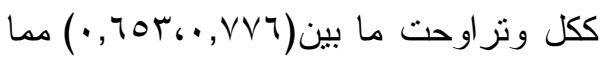

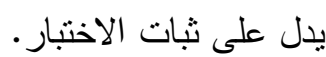
r-اختبار القدرة على اتخاذ القرار:

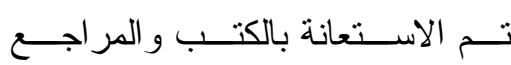

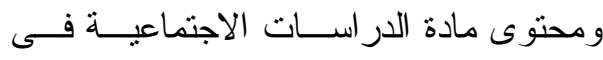

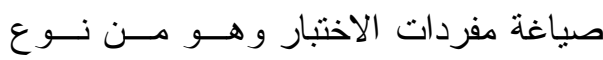
الاختيار من متعدد .

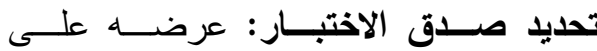
المحكمين وتعديله فى ضوء آر ائهم.

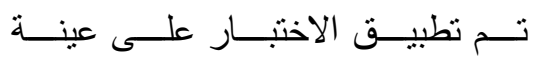
استطلاعية (•r) تلميذة وذلك بهدف تحديد:

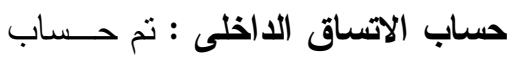

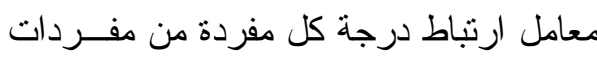

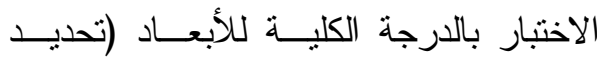
المشكلة- توليد البدائل- نقييم البدائل - اتخاذ

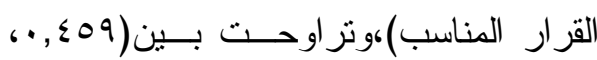
7 (9 , · ) و هى موجبة وذات دلالة إحسـصائية

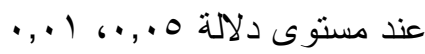

تم حساب معامــل ارتبـــاط الدرجــة الكلية للأبعاد (تحديد المشكلة- توليد البدائل-

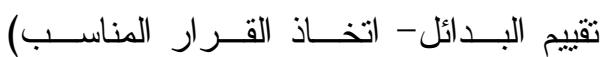

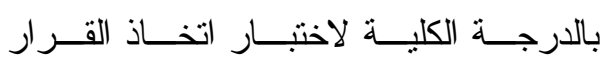

$$
\text { إجراءات البحث : }
$$

1- اختبار مهارات التفكير التأملى :

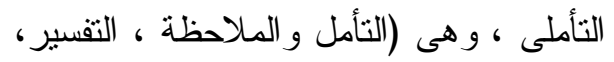
التحليل، الاستتناج، الكثف عن المغالطات)، وعرضها على المحكمين وتعديلها. صياغة مفردات الاختبار: من خــلهل

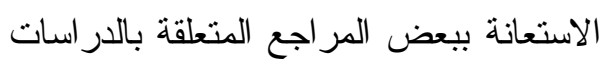

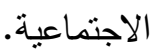

تحديد صدق الاختبار: عرضه عايه عـى المحكمين وتعديله فى ضو ء آر ائهم.

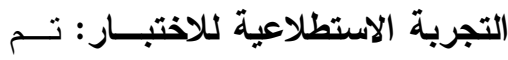
تطبيقه على عينة استطلاعية (•r) تلميـذة حساب الاتساق الداخلى :تم حسساب :

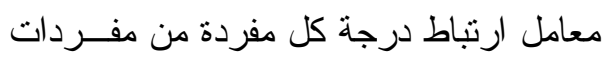
اختبار التفكيــر التــأملى بالدرجـــة الكليـــة

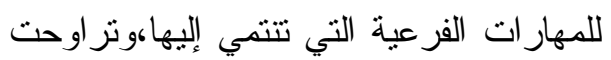

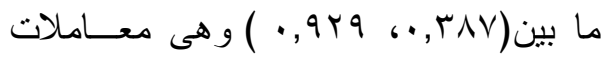

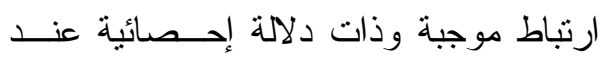

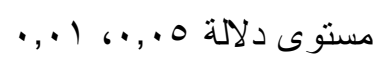

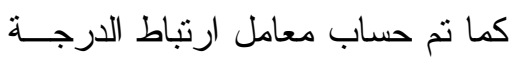
الكلية للمهارات الفرعيــة بالدرجـــة الكليــة

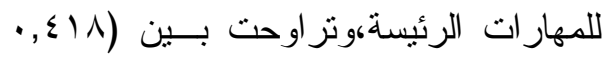

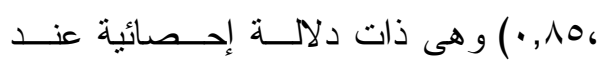

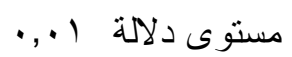
تم حساب معامل ارتباط الدرجة الكلية للمهار ات الرئيسة بالدرجة الكلية للاختبار و 
عرض البرنــامج علـى المحكمــين

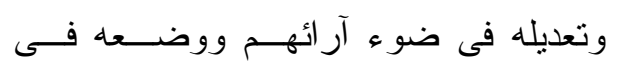
صورته النهائية.

اعداد دليل المعلم لتدريس البرنــامج

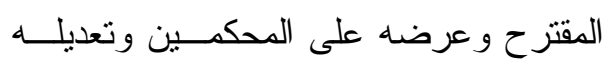
ووضعه فى صورته النهائية . تطبيق أدوات البحث :

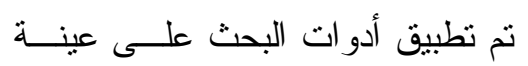

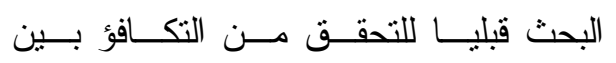

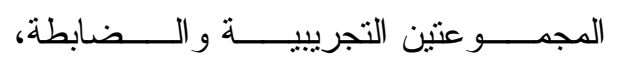
و استخدمت الباحثة اختبار " ت" للمجموعات لتهن

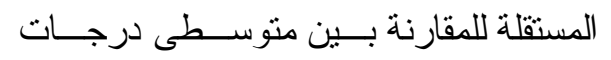
المجمو عتين على ثلك الأدو ات،

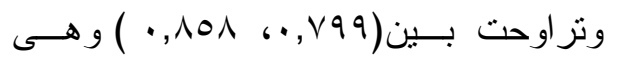

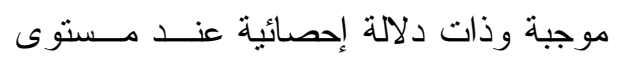
دلالة ا.,., حساب ثبات الاختبار تم حساب الثبات بمعادلة ألفا كرونباخ لأبعاد اختبــار القــدرة

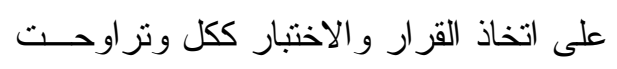

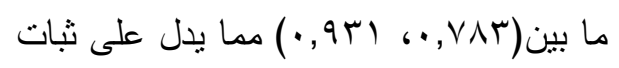

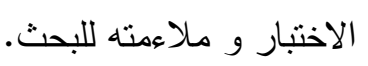

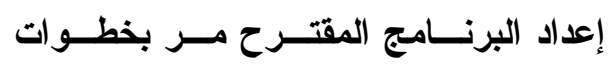
وهى :

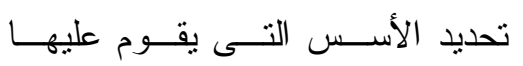

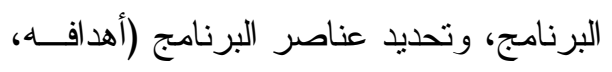

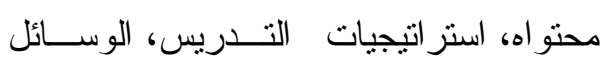
و الأنشطة، التقويم) التنز

\section{جدول( )}

يوضح قيمة " ت " ودلالتها الإحصائية للفروق بين متوسطي درجات المجموعتين التجريبية و

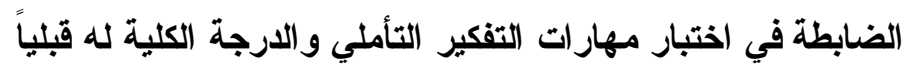

\begin{tabular}{|c|c|c|c|c|c|c|c|}
\hline مستوى & الدرجية & قيمة (ت) & الالحعراف & المتوسط & $\dot{~ ن}$ & المجموعة & أبعاد اختبار مهار ات التفير \\
\hline \multirow{2}{*}{ غير دالة } & \multirow{2}{*}{$7 \wedge$} & \multirow{2}{*}{$1, Y 19$} & . , हा० & $1, r \varepsilon$ & r & التجريبية & \multirow{2}{*}{ أولاً: التأمل و الملاحظة. } \\
\hline & & & $\cdot, \leqslant q r$ & $1, \Gamma \wedge$ & rV & الضابطة & \\
\hline \multirow{2}{*}{ غير دالة } & \multirow{2}{*}{71} & \multirow{2}{*}{$\cdot, 711$} & $\cdot, 1 \vee 90$ & r,Or & 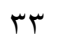 & التجريبية & \multirow{2}{*}{ ثانياً: إعطاء تفسير ات } \\
\hline & & & $1, \ldots 1$ & $r, 70$ & rV & الضابطة & \\
\hline \multirow{2}{*}{ غير دالة } & \multirow{2}{*}{71} & \multirow{2}{*}{1,10} & $\cdot, \times 01$ & $r, 01$ & r & التجريبية & \multirow{2}{*}{ ثالثاً: التحليل. } \\
\hline & & & $\cdot, 1 \vee 90$ & $r, 9 r$ & $r v$ & الضابطة & \\
\hline \multirow{2}{*}{ غير دالة } & \multirow{2}{*}{71} & \multirow{2}{*}{$\cdot, 1 \wedge 9$} & $\cdot, \wedge \neg \leqslant$ & $r, r q$ & rr & التجريبية & \multirow{2}{*}{ رابعاً: الاستنتاج. } \\
\hline & & & 1 & r,ro & $r v$ & الضابطة & \\
\hline \multirow{2}{*}{ غير دالة } & \multirow{2}{*}{71} & \multirow{2}{*}{$\cdot, \wedge 7 \leqslant$} & $\cdot, 719$ & $r, \Sigma \Lambda$ & r & التجرييية & \multirow{2}{*}{ خامسا: الكشف عن المغالطات. } \\
\hline & & & $\cdot, 919$ & $r, 70$ & $r v$ & الضابطة & \\
\hline \multirow{2}{*}{ غير دالة } & \multirow{2}{*}{$7 \wedge$} & \multirow{2}{*}{$1, \cdot r r$} & $r, 719$ & $11, Y_{1}$ & r & التجريبية & \multirow{2}{*}{ الارجة الكلية } \\
\hline & & & $r, r q 9$ & 11,90 & rV & الضابطة & \\
\hline
\end{tabular}


و الضـابطة فــي اختبــار مهـــار ات التفكيــر

يتضح من نتــائج الجــدول الــسابق

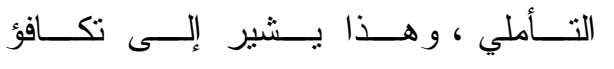

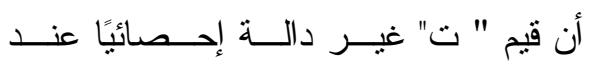

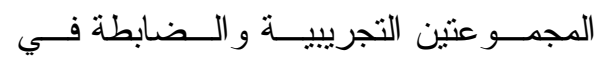

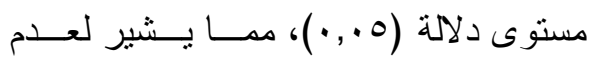

اختبار مهار ات التفكير التأملى قبليا.

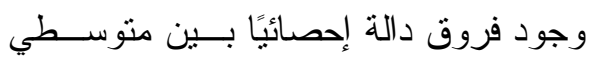

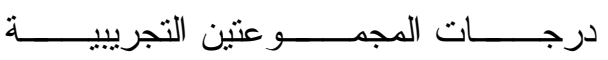

جدول (ץ) قيمة " ت " ودلالتها الإحصائية للفروق بين متوسطي درجات

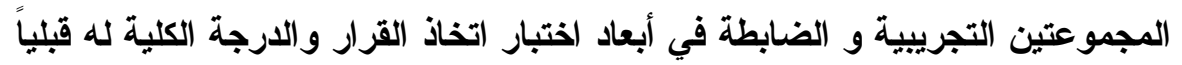

\begin{tabular}{|c|c|c|c|c|c|c|c|}
\hline مستوى الدالة & لدرجية & قيمة (ت) & الالحعرافي & المتوسط & ن & المجموعة & أبعاد القتبار اتخاذ \\
\hline \multirow{2}{*}{ غير دالة غ } & \multirow{2}{*}{71} & \multirow{2}{*}{ 1, OVY } & ك & $r, \varepsilon r$ & ז & التجريبية & \multirow{2}{*}{ تحديد المشكلة } \\
\hline & & & $\cdot, v \cdot q$ & $r, 7 \Lambda$ & $r v$ & الضابطة & \\
\hline \multirow{2}{*}{ غير دالة } & \multirow{2}{*}{ 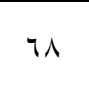 } & \multirow{2}{*}{ •, or } & $\cdot, \wedge \Gamma \varepsilon$ & $r, 10$ & r & التجريبية & \multirow{2}{*}{ توليد البدائل } \\
\hline & & & $\cdot, \vee \vee ०$ & $r, 90$ & $r v$ & الضابطة & \\
\hline \multirow{2}{*}{ غير دالة } & \multirow{2}{*}{71} & \multirow{2}{*}{$\cdot, \varepsilon \vee \leqslant$} & $\cdot, 7.9$ & $r, T)$ & זr & التجرييية & \multirow{2}{*}{ تقييم البدائل } \\
\hline & & &., 971 & $r, 01$ & $r v$ & الضابطة & \\
\hline \multirow{2}{*}{ غير دالة } & \multirow{2}{*}{71} & \multirow{2}{*}{$\cdot, \Gamma \wedge q$} & $\cdot, \wedge T \leqslant$ & $r, r q$ & r & التجريبية & \multirow{2}{*}{ اتخاذ القرار المناسب } \\
\hline & & & $1, .97$ & $r, \leqslant q$ & $r v$ & الضابطة & \\
\hline \multirow{2}{*}{ غير دالة } & \multirow{2}{*}{719} & \multirow{2}{*}{$\cdot, 719$} & $r_{,} \cdot r_{0}$ & $1 \cdot, r V$ & r & التجرييية & \multirow{2}{*}{ اللارجة الكلية } \\
\hline & & & $r, Y \cdot V$ & $1 \cdot, \pi T$ & $r v$ & الضابطة & \\
\hline
\end{tabular}

وتم التدريس للمجموعة الضابطة المتمنلة فى يتضح من نتائج الجدول السابق أن قيم

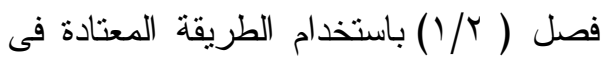

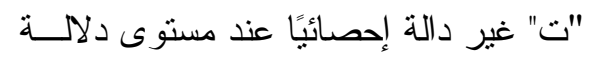
التدريس ،وذذلك بمدرسة ميت على الإعدادية

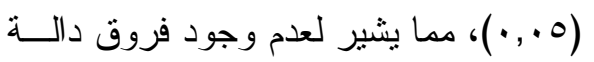

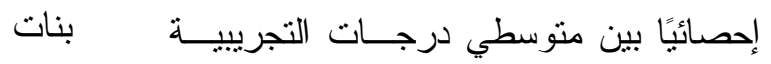

ثم تطبيق أدوات البحث بعديا علــى

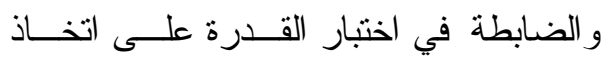
مجموعتى البحث وتصحيح الأدوات ورصد لُوند

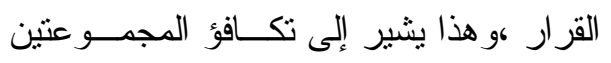
الدارجات.

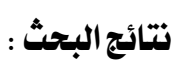

نتائج الفرض الأول : يوجد فرق دال

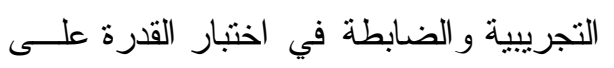
اتخاذ القرار قبليا.

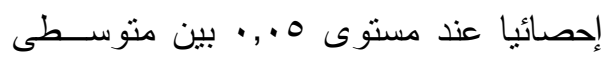
تنفيذ تجربة البحث :

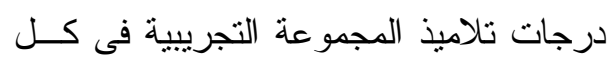
قامــت الباحثــة بتــدريس البرنـــامج

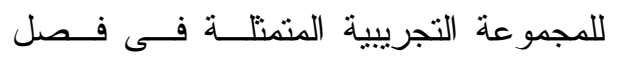
( / ( ) وذلك بمدرسة طناح الاعدادية بنات، 
درجات النطبيق القبلي و البعدي للمجموعــة

من التطبيقين القبلى و البعدى لاختبار مهارات التجريبية في اختبار مهار ات التفكير التأملي

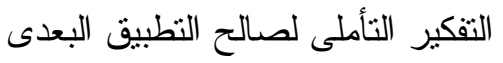

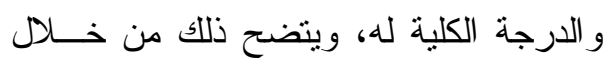

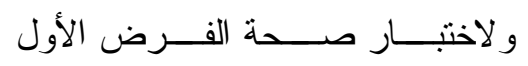

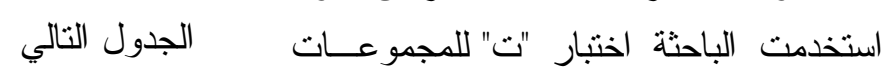
المرتبطة لتحديد دلالة الفروق بين منوسطي جدول (r) قيمة " ت " ودلالتها الإحصائية للفروق بين متوسطي درجات التطبيقين القبلي

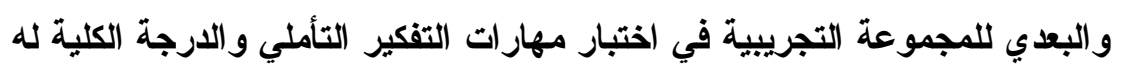

\begin{tabular}{|c|c|c|c|c|c|c|c|}
\hline مستوي & ل الرجية & قيمة "ت" & الالحير اف & المتوسط & ن & التطبيق & أبعاد اختبار مهارات التفكير \\
\hline \multirow{2}{*}{$\cdot, \cdot 1$} & \multirow{2}{*}{ rT } & \multirow{2}{*}{ 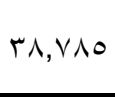 } &.,$\leqslant$ To & $1, r \varepsilon$ & \multirow{2}{*}{ r } & قبلى & \multirow{2}{*}{ أولاً: التأمل و الملاحظة. } \\
\hline & & & . & 0,10 & & بعدي & \\
\hline \multirow{2}{*}{$\cdot, \cdot}$, & \multirow{2}{*}{ r } & \multirow{2}{*}{ TO, YTV } & $\cdot, \times 90$ & r,or & \multirow{2}{*}{ 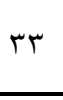 } & قبلي & \multirow{2}{*}{ ناتياً: اعطاء تفسيرات مقتعة. } \\
\hline & & & $\cdot, 719$ & $V, \varepsilon \wedge$ & & بعدي & \\
\hline \multirow{2}{*}{$\cdot, \cdot 1$} & \multirow{2}{*}{ rT } & \multirow{2}{*}{ rq, ह17 } & $\cdot, \mathrm{V} 01$ & $r, 01$ & \multirow{2}{*}{ זr } & قبلى & \multirow{2}{*}{ ثالثاً: التحليل. } \\
\hline & & & •, rवY & $v, 91$ & & بعدي & \\
\hline \multirow{2}{*}{$\cdot, \cdot 1$} & \multirow[t]{2}{*}{ rr } & \multirow{2}{*}{$r 0, \wedge 01$} & $\cdot, \wedge \uparrow \leqslant$ & $r, r q$ & \multirow[t]{2}{*}{ זr } & قبلى & \multirow{2}{*}{ رابعاً: الاستتتاج. } \\
\hline & & & .071 & $\mathrm{~V}, \mathrm{VT}$ & & بعدي & \\
\hline \multirow{2}{*}{$\cdot, \cdot}$, & \multirow{2}{*}{ r } & \multirow{2}{*}{$\varepsilon \varepsilon, \cdot \wedge$} & $\cdot, 719$ & $r, \varepsilon \wedge$ & \multirow{2}{*}{ س } & قبلي & \multirow{2}{*}{ خامساً: الكثف عن المغات } \\
\hline & & & 政. & $\gamma, \wedge 0$ & & بعدي & \\
\hline \multirow{2}{*}{$\cdot, \cdot}$, & \multirow{2}{*}{ rr } & \multirow{2}{*}{$T \cdot, \varepsilon r$} & $r, 719$ & $11, r)$ & \multirow{2}{*}{ זr } & قبلى & \multirow{2}{*}{ الارجة الكلية } \\
\hline & & & $1, \wedge \Gamma q$ & $M-10$ & & بعدي & \\
\hline
\end{tabular}

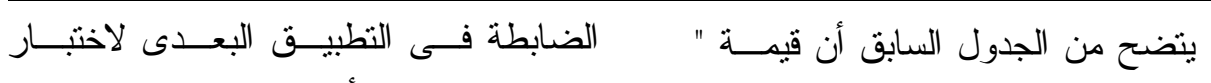

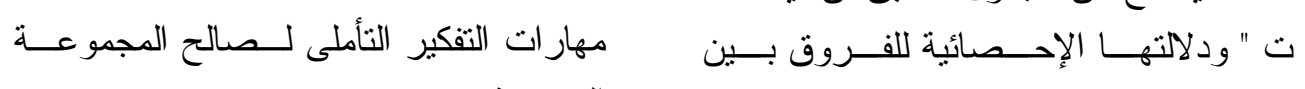

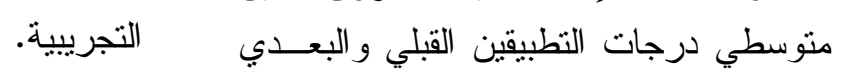

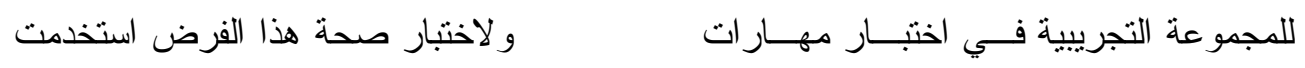

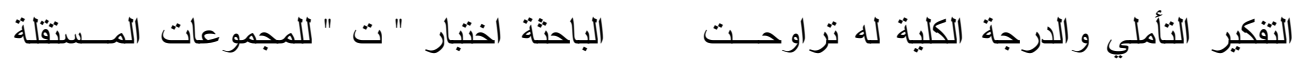

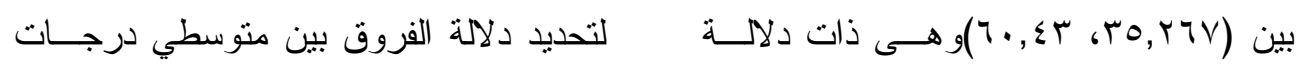

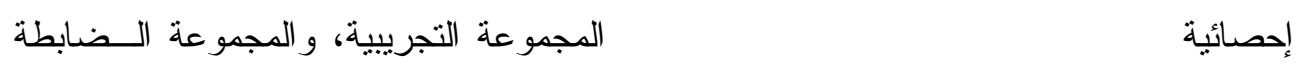

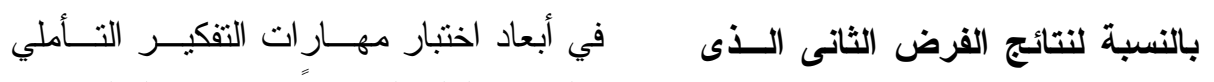

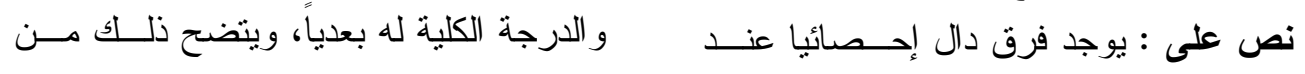

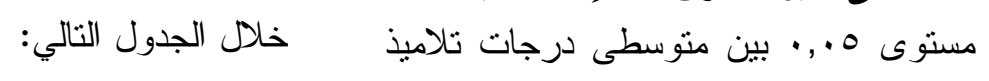

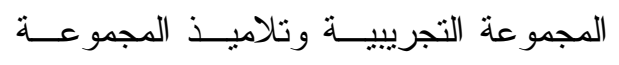


جدول (؛ ) قيمة " ت " ودلالتها الإحصائية للفروق بين متوسطي درجات المجموعتين التجريبية

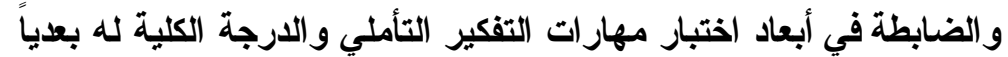

\begin{tabular}{|c|c|c|c|c|c|c|c|}
\hline مستوى الدلاية & الحرية & قيمة (ت) & الالمعر افياري & المتوسط & $\dot{ن}$ & المجموعة & أبعاد اختبار مهار ات التفير التملي \\
\hline \multirow{2}{*}{$\cdot, \cdot 1$} & \multirow{2}{*}{$7 \wedge$} & \multirow{2}{*}{$r \leq, 99 \leq$} & ש & 0,10 & r & التجريبية & \multirow{2}{*}{ ولاً: التأمل و الملاحظة. } \\
\hline & & & $\cdot, 0 . V$ & $r, \leqslant q$ & rV & الضابطة & \\
\hline \multirow{2}{*}{$\cdot, \cdot 1$} & \multirow{2}{*}{$7 \wedge$} & \multirow{2}{*}{ 19,AYT } & $\cdot, 719$ & $\mathrm{~V}, \varepsilon \wedge$ & r & التجريبية & \multirow{2}{*}{ ثانياً: إعطاء تفسير ات } \\
\hline & & & י & $r, 9 \vee$ & $r v$ & الضابطة & \\
\hline \multirow{2}{*}{$\cdot, \cdot 1$} & \multirow{2}{*}{71} & \multirow{2}{*}{ 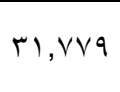 } & $\cdot, r q Y$ & $V, 91$ & r & التجريبية & \multirow{2}{*}{ ثالثاً: التحليل. } \\
\hline & & & $\cdot, 7 \leq 0$ & $\varepsilon, \cdot r$ & rV & الضـابطة & \\
\hline \multirow{2}{*}{$\cdot, \cdot 1$} & \multirow{2}{*}{71} & \multirow{2}{*}{$r V, 0 \leq V$} &., 071 & $V, V T$ & r & التجرييية & \multirow{2}{*}{ رابعاً: الاستنتاج. } \\
\hline & & &., $70 \mathrm{r}$ & $r, v r$ & $r v$ & الضابطة & \\
\hline \multirow{2}{*}{$\cdot, \cdot 1$} & \multirow{2}{*}{$7 \wedge$} & \multirow{2}{*}{ rr, IVT } & $\cdot, 77 \mathrm{~V}$ & $\vee, \wedge 0$ & r & التجريبية & \multirow{2}{*}{ خامسا: الكشف عن المغالطات. } \\
\hline & & &., 997 & $r, r$ & $r v$ & الضـابطة & \\
\hline \multirow{2}{*}{$\cdot, \cdot 1$} & \multirow{2}{*}{$7 \wedge$} & \multirow{2}{*}{ 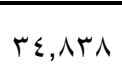 } & 1,149 & $r 4,10$ & $r$ & التجريبية & \multirow{2}{*}{ الارجة الكلية } \\
\hline & & & r,OT & $1 V, 01$ & rV & الضانطة & \\
\hline
\end{tabular}

التعلم أصبحت كموجهات لهـن أثثــاء عملية التعلم.

r - ما يتضمنه البرنامج من موضـــوعات ذات صلة وثنيقـة بحيــاة التلمبــذات، ويناقش قضايا المجتمع الذى يعشن فيه مما جعل تعلم المادة المتعلمة بطريقـة اكثر نشويقا

r- ما يحتويه البرنامج القائم على البنائية من أنشطة تعليمبــة متتوعــة تقـيس مستويات متعددة من التفكير التــأملى ملى تتناسب مع التباين فى قدر ات التلمبذات المختلفة . اختبار صحة الفرض الثالث ، وهو: يوجد فرق دال إحصائيا عند مـستوى 0 . , • بين متوسطى درجات تلاميذ المجموعة
يتضح من الجدول نزاوحت قيمة ت

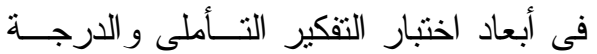

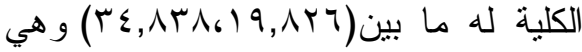
قيم ذات دلالة إحصائية عند مستوي دلالـــة $\cdots, \cdot 1$

مناقشة نتائج التفكير التأملى وتفسيرها : أظهرت النتــائج فعالبـــة البرنـــامـج المقترح فى الدر اسات الاجنماعية القائم على النظرية البنائية فى تتمية بعـــ مهــار ات التفكير التأملى لدى المجموعـــة التجريبيــة

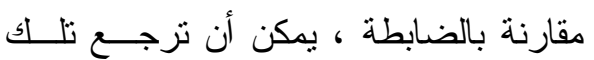
الفعالية إلى عدة عو امل ،هى : ا- أن البرنامج القائم علــى النظريــــة البنائية اتاح للتلميذات التعرف علـى الأهداف المرجو تحقيقها قبل عمليــة 
بين منوســـي درجــات التطبيقـين القبالــي

التجريبية فى كل مــن التطبيقــين القبلـى و البعدي للمجموعة التجريبية في أبعاد اختبار و البعدى لاختبار القدرة على اتخاذ القـــرار

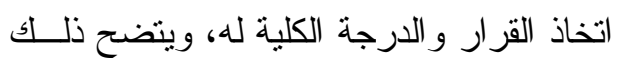

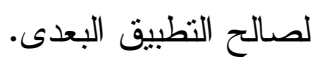

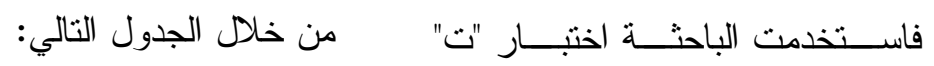
للمجموعات المرتبطة لتحديد دلالة الفــروق لـات جدول (0)

قيمة " ت " ودلالتها الإحصائية للفروق بين متوسطي درجات التطبيقين القبلي والبعدي جي

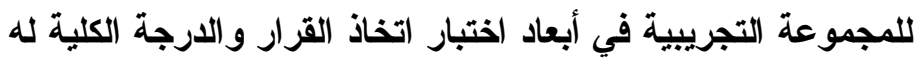

\begin{tabular}{|c|c|c|c|c|c|c|c|}
\hline مستوي & الحرية & قيمة "ت" & الاحر اف المعياري & المتوسط & $\dot{ن}$ & التطبيق & أبعاد اختبار اتخاذ \\
\hline \multirow{2}{*}{$\cdot, \cdot 1$} & \multirow{2}{*}{ rt } & \multirow{2}{*}{$r V, T V Y$} & $\cdot, 71 \leq$ & $r, \leqslant r$ & \multirow{2}{*}{ سז } & قبلي & \multirow{2}{*}{ تحديد المشكلة } \\
\hline & & &., 0.7 & $\vee, 00$ & & بعدي & \\
\hline \multirow{2}{*}{$\cdot, \cdot 1$} & \multirow{2}{*}{ rt } & \multirow{2}{*}{$r \leq, V 01$} & •, & $r, \wedge 0$ & \multirow{2}{*}{ 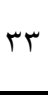 } & قبلي & \multirow{2}{*}{ توليد البدائل } \\
\hline & & & $\cdot, 7 \cdot \pi$ & $V, T \varepsilon$ & & بعدي & \\
\hline \multirow{2}{*}{$\cdot, \cdot 1$} & \multirow{2}{*}{ rt } & \multirow{2}{*}{ rᄉ } & $\cdot, 7.9$ & $r, 7)$ & \multirow{2}{*}{ זי } & قبلي & \multirow{2}{*}{ تقييم البدائل } \\
\hline & & &., $0 \leq 0$ & $\Lambda, 1 Y$ & & بعدي & \\
\hline \multirow{2}{*}{$\cdot, \cdot 1$} & \multirow{2}{*}{ rt } & \multirow{2}{*}{$r, r \wedge$} & $\cdot, \wedge T \leq$ & $r, r q$ & \multirow{2}{*}{ " } & قبلي & \multirow{2}{*}{ التخاذ القرار } \\
\hline & & & $\cdot, 9 \vee V$ & $\Lambda, r V$ & & بعدي & \\
\hline \multirow{2}{*}{$\cdot, \cdot 1$} & \multirow{2}{*}{ rt } & \multirow{2}{*}{0,17} & r, ro & $1 \cdot, Y V$ & \multirow{2}{*}{ 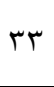 } & قبلي & \multirow[t]{2}{*}{ الارجة الكلية } \\
\hline & & & $1, \Gamma \leq V$ & M, & & بعدي & \\
\hline
\end{tabular}

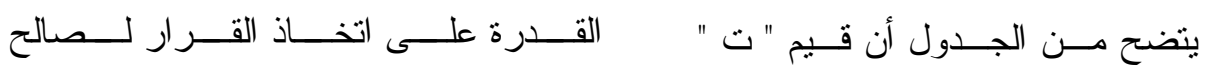
المجموعة التجريبيــة ،اســتخدمت الباحثــة

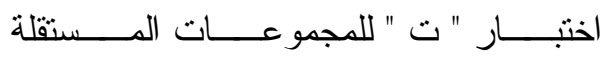

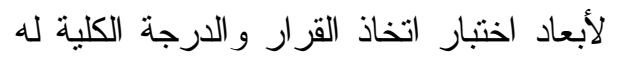

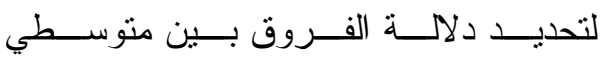
تز اوحت بين(

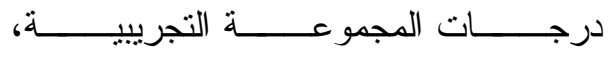

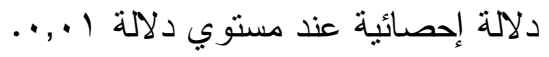
و المجموعة الــضابطة فــي أبعــاد اختبـــار

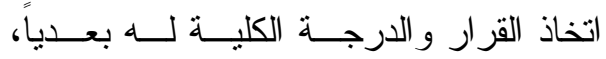
ويتضح ذللك من خلا الجدول التالي: لاختبار صحة الفرض الرابع :

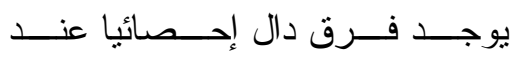

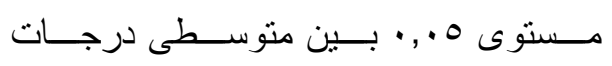

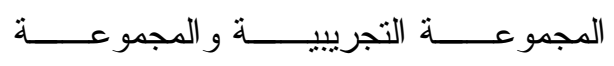
الضابطة فــى التطبيــق البعـــى لاختبـــار 


\section{جدول (1)}

قيمة " ت " ودلاتتها الإحصائية للفروق بين متوسطي درجات المجموعة التجريبية والمجموعة

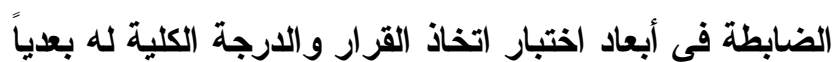

\begin{tabular}{|c|c|c|c|c|c|c|c|}
\hline مستوى الدلالة & الحرية & قيمة (ت) & الآحعراف & المتوسط & ن & المجموعة & أبعاد اختبار اتخاذ \\
\hline \multirow{2}{*}{$\cdot, \cdot 1$} & \multirow{2}{*}{$7 \wedge$} & \multirow{2}{*}{$r v, 011$} & $\cdot, 0.7$ & $\vee, \infty 0$ & rr & التجريبية & \multirow{2}{*}{ تحديد المشكلة } \\
\hline & & & $\cdot, 717$ & $r, \wedge 1$ & $r v$ & الضابطة & \\
\hline \multirow{2}{*}{$\cdot, \cdot 1$} & \multirow{2}{*}{71} & \multirow{2}{*}{$r Y, \Sigma \wedge T$} & $\cdot, 7 \cdot r$ & $V, T \varepsilon$ & אי & التجريبية & \multirow{2}{*}{ توليد البدائل } \\
\hline & & & $\cdot, 799$ & $\varepsilon, 11$ & rv & الضابطة & \\
\hline \multirow{2}{*}{$\cdot, \cdot 1$} & \multirow{2}{*}{71} & \multirow{2}{*}{$r T, r \leq$} &., $0 \leqslant 0$ & $\Lambda, 1 \mathrm{r}$ & r & التجريبية & \multirow{2}{*}{ تقييم البدائل } \\
\hline & & & $\cdot, 7 \cdot V$ & $\varepsilon, \leqslant 9$ & rv & الضابطة & \\
\hline \multirow{2}{*}{$\cdot, \cdot 1$} & \multirow{2}{*}{71} & \multirow{2}{*}{19,94} & $\cdot 9 \vee V$ & $\Lambda, r V$ & rr & التجريبية & \multirow{2}{*}{ التخاذ القزار } \\
\hline & & & $\cdot, \leqslant \vee 0$ & $\varepsilon, 7 \Lambda$ & rv & الضابطة & \\
\hline \multirow{2}{*}{$\cdot, \cdot 1$} & \multirow{2}{*}{71} & \multirow{2}{*}{$\varepsilon r, \cdot V$} & $1, r \leqslant V$ & $M, 01$ & r & التجرييية & \multirow{2}{*}{ للازختبار الكلية } \\
\hline & & & 1,017 & $I V, \cdot A$ & rv & الضابطة & \\
\hline
\end{tabular}

على اتخاذ القرار الذى يهــدف إلـى الوصول إلى حلول منلى للمشكلة. ץ- الأنشطة و المو اقف التعليميــة التـى لـى تتطلبها مر احل نموذج التعلم البنــائى ولئى تنتاسب مع مر احل اتخاذ القرار حيث

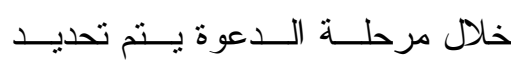

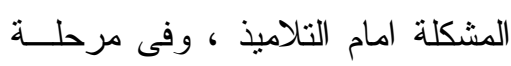
الاستكثاف يتم ممارسة الأنشطة التى وفى مرحس من خلالها يكتشف التلاميذ معلومات

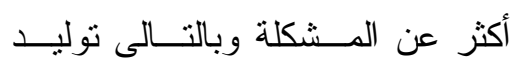
البدائل المختلفة، وفى مرحلة اقتــراح الحلول و التفسير ات ينم اقتر اح الحلول وتقييمها،وفى مرحلة التطبيـق بـتـن اتخاذ القر ار
يتضح من الجدول السابق ما يلي: أن

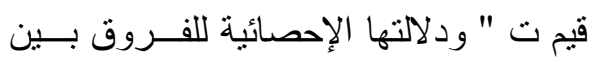
متوسطي درجـات المجموعـــة التجريبيــة و المجموعة الضـابطة في أبعاد اتخاذ القـــرار و الدرجة الكلية له بعديا تتر اوح بين (19,9, 19.

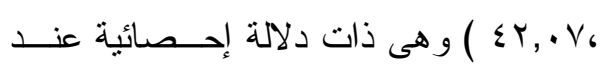

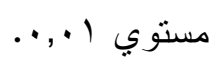

\section{مناقشة نتائج القدرة على اتخاذ القراروتفسيرها} ترجع فعالية البرنامج فى تنمية القدرة على اتخاذ القرار لدى المجموعة التجريبية إلى : 1- المـشكلات المعروضـــة بالبرنــامج تتطلب البحث عن عدة بدائل لحل نلالك بلك المشكلات مما يؤدى إلى تتمية القدرة 
وتتمية التفكير و النظريـــة البنائيــة ،

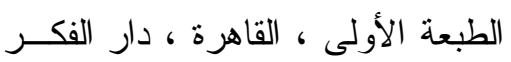

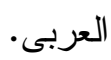

r- حنان إبر اهيم الدسوقى (10 • ب):فاعليـــة

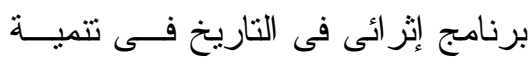

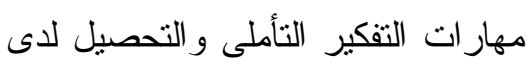

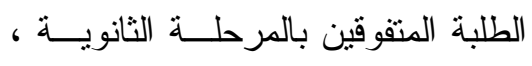
مجلة الجمعية التربويــة للار اســات

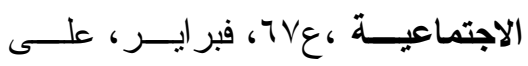

$$
\text { الر ابط : }
$$

http://search.mandumah.com/Reco $\mathrm{rd} / 722718$

$$
\begin{aligned}
& \text { r- خالد عبد اللطيــف عمـران (9 . . r ): }
\end{aligned}
$$

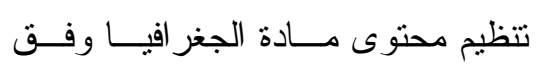

$$
\begin{aligned}
& \text { نظرية ريجليوث التوسعية وأثره علــى لنى }
\end{aligned}
$$

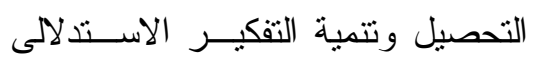

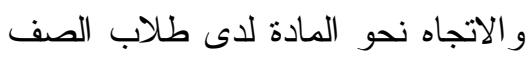

$$
\begin{aligned}
& \text { الأول الثانوى، دراسات فى المنــــاهج }
\end{aligned}
$$

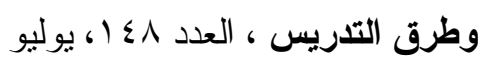

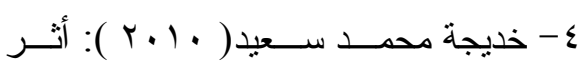

$$
\begin{aligned}
& \text { استر اتيجيات النظرية البنائية فى تتمية }
\end{aligned}
$$

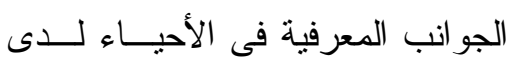

$$
\begin{aligned}
& \text { طالبات المرحلة الثانوية ، مجلة مستقبل }
\end{aligned}
$$

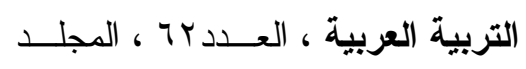

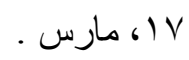

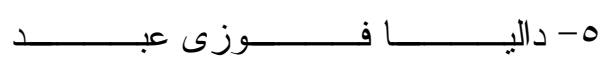

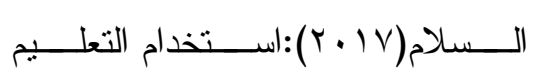

\section{توصيات البحث :}

1 - إعادة بناء وتخطيط مناهج الدر اســات

الاجتماعية بمر احل التعليم العام لتكون

هدفها التربوى الاساسى تتمية مهار ات التهرئ

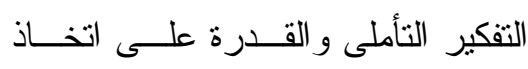

$$
\text { القرار }
$$

r- استخدام تكنولوجيا التعليم الحديثة فـى

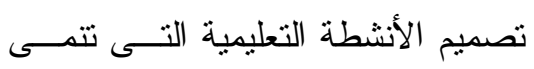

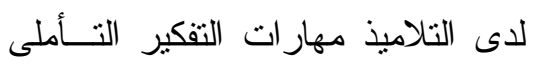

المتتوعة و القدرة على اتخــاذ القـــرار

تجاه المو اقف الحياتية المتعلقة بمنــاهج

الدر اسات الاجتماعية.

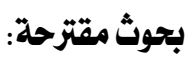

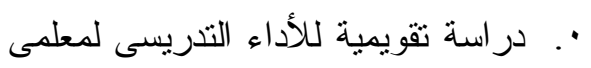

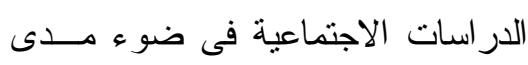

قدرتهم على تتمية مهـار ات التفكيــر

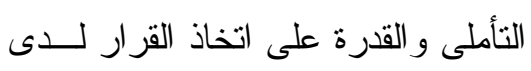

$$
\text { ن تلاميذهم }
$$

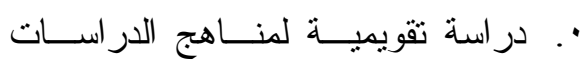

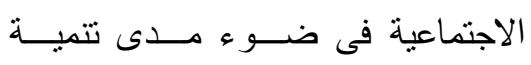

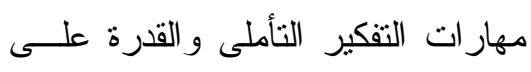

اتخاذ القرار لدى تلاميذ مراحل التعليم

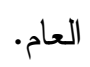

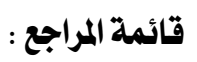

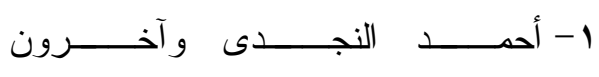

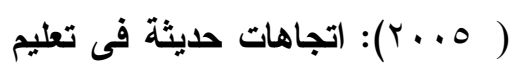

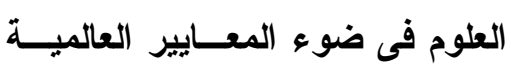


تلاميذ المرحلـــة الاعداديـــة ، مجلـــة

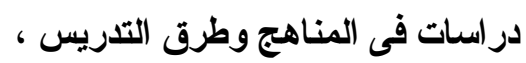

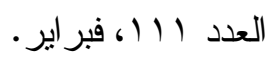

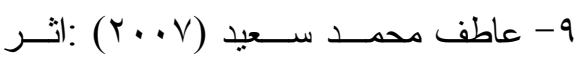

$$
\text { اســتخدام نمــوذج ريجليــوث }
$$

تلتـــeieluted

تدريس التاريخ على التحصيل وتتميــة

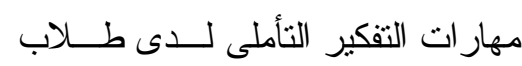

الصف الأول الثانوى ، مجلة الجمعية

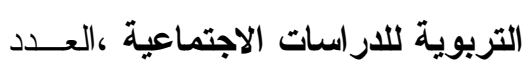

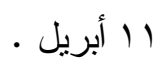

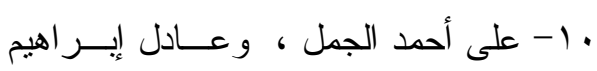

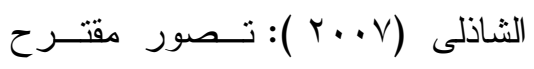

لمحتــوى مسـنهج التــاريخ وتدريسـسه

بالمرحلة الثانوية فى ضوء هـ نظريــات

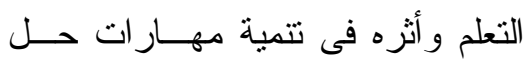

المشكلات لاى الطلاب،مجلة الجمعية

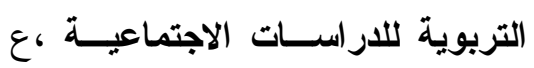

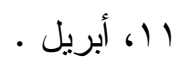

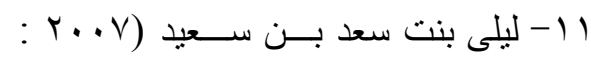

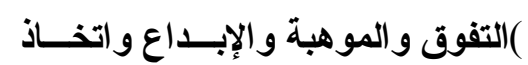

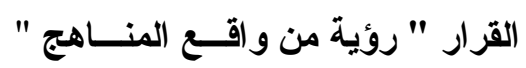

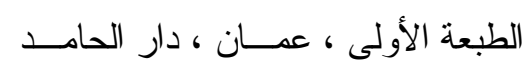

$$
\text { للنشر . 1ل }
$$

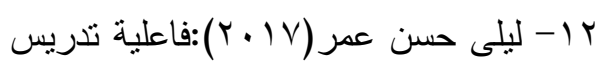

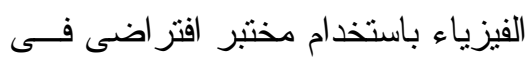

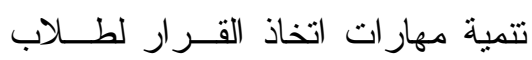

المتمايز في تتميــة التفكيــر التــأملى

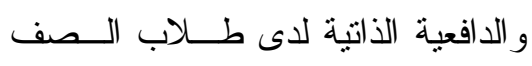

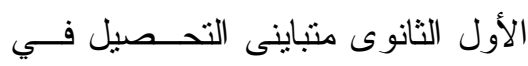

مـــادة الجغر افيــا، مجلــــة الجمعيـــة

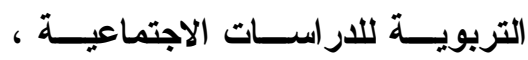

ع و 9، أغسطس،على الر ابط

http://search.mandumah.com/Reco $\mathrm{rd} / 862222$

Y- زينب محمد عبد الله (Y • Y Y) : فاعليــة

التعلم الإستر اتيجى فى نتمية التحصيل

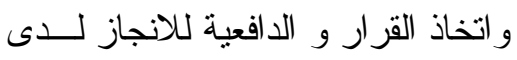
طلاب المرحلة الثانوية ، رسالة دكتور اه غير منشورة ، كلية البنات ، جامعة عين

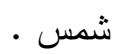

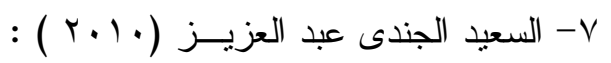

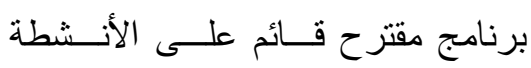

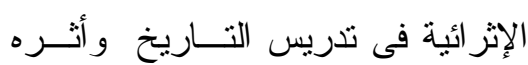

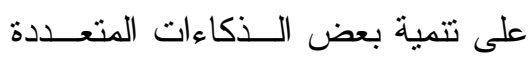

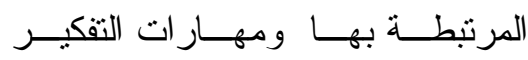
التباعدى لاى طلاب المرحلة الإعدادية

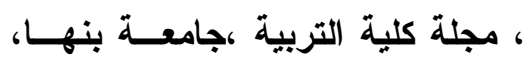

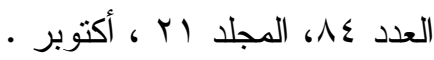

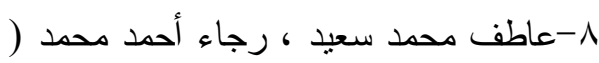

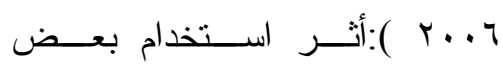
استر اتيجيات التعلم النشط فى تــدريس الدراسات الاجتماعية على التحــصيل وتتمية مهار ات حل المـشكلات لــدى الـى 
IV

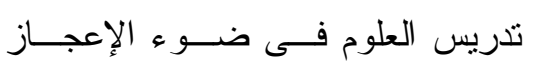

العلمى القر آنى فى تتمية التفكير التأملى لـى لألى

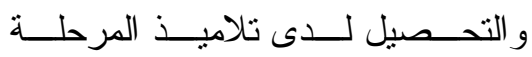

الإعدادية الأزهرية ، رسالة ماجسستير

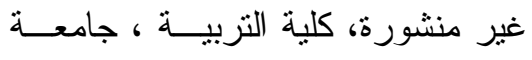

دمياط

18- Akpinar,E. ,\&et al (2009): Developing A scale aiming at determining The application of Constructivist approach in Science Course, Procedia Social and Behavioral Sciences, vol.1.

$19-$ (2009): The role of Cognitive Conflict in Constructivist

theory : An Implementation aimed at science teachers, Procedia Social and Behavioral Sciences,vol. 1 .

20- AKyol ,S. \&Fer,s.,(2010) : Effects of Social Constructivist Learning Environment Design On 5th Grade Learning, Procedia Social and Behavioral Sciences, v.9.

$12-$

Charoenchai ,s.(2012):Collaborative action research to promote reflective

thinking among higher education students , Procedia- Social and

$$
\begin{aligned}
& \text { المرحلة الثانويــة بدولـــة ليبيا،رســالة } \\
& \text { ماجستير غير منشورة ، كلية التزبيــة، } \\
& \text { جامعة دمياط . } \\
& \text { r ا - ماهر شعبان عبد البـارى ( • • r ) : } \\
& \text { استر اتيجيات فهم المقروء " أسـسهران } \\
& \text { النظرية وتطبيقاتها العملية " ، الطبعة } \\
& \text { الأولى ، عمان ، دار المسيرة. }
\end{aligned}
$$

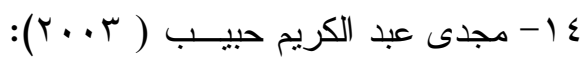

تعليم التفكير فى عصر المعلومسـات ،

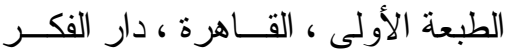

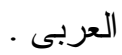

10 - ملاك بنت محمد الـسليم( 9 . . ب ) :

فاعلية التعلم التأملى فى نتمية المفــاهيم

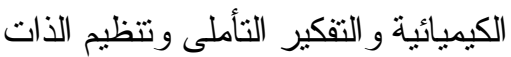

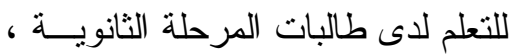

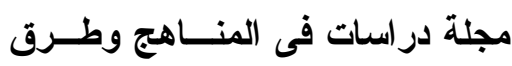

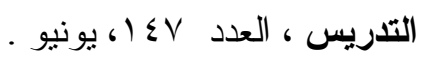

17 - ممدوح محمد عبد المجيد ، وعبــد الله

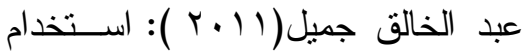

أطلس المفاهيم فـى تــدريس وحــدة

مقترحة قائمة على التكامل بين مفاهيم

مادتى العلوم و الدراسات الاجتماعيــة علــى تتميـــة التحـــصيل و التقكيــــر

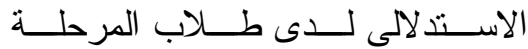

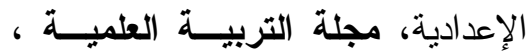

العدد r، المجلد ؟ ا ، أبريل . 
conceptual learning

capabilities in science lessons

, Procedia Social and

Behavioral Sciences, vol. 2

26-Kurt ,s. (2011) : Use of Constructivist approach in architectural education , Procedia Social and Behavioral Sciences, vol. 15

27-Wilson, L.(2008): Practical Teaching A Guide to PtLLs \& CTLL , Library Britain .

28-Yampinij ， s. (2012) : The Validation of Knowledge Construction model based on Constructivist Approach to support ILLstructured

problems solving process for industrial education and technology students, Procedia Social and Behavioral Sciences,vol.46

29-Zhang ,Q. \&Kou,Q. (2012) :The Course Research for the software

Program Based on the Constructivism Teaching Theories, Physics Procedia ,vol.25.
Behavioral Sciences, Vol. 47 .

22-Demirci,c.(2010) : Constructing a philosophy : prospective teachers

opinions about Constructivism, ProcediaSocial and Behavioral Sciences, Vol. 9 .

23- Guvence,Z.(2012) : The Relationship between the Reflective Thinking skills and Emotional Intelligences of Class Teachers , International Journal of Humanities and Social Science, Vol. 2,No.16

24-Karaduman ,H.(2007) : The Effect of constructivist learning Principles Based learning Materials To Students Attitudes, Success And

Retention In social Studies ,The Turkish Online Journal of

Educational

Technology,Vol.6, Issue 3 , July.

25-Kilic ,O.\&Gurdal ,A.(2010):

The influence of Constructivism With family and instructor support on students success and 